\title{
Reduced physiological performance in a free-living coralline alga induced by salmon faeces deposition
}

\author{
Erwann Legrand ${ }^{1, *}$, Tina Kutti ${ }^{1}$, Erika V. Gonzalez Casal ${ }^{1}$, Samuel P. S. Rastrick ${ }^{1}$, \\ Sissel Andersen ${ }^{2}$, Vivian Husa ${ }^{1}$
}

${ }^{1}$ Institute of Marine Research, Nordnesgaten 50, 5005, Bergen, Norway

${ }^{2}$ Institute of Marine Research, Austevoll Research Station, 5392 Storebø, Norway

\begin{abstract}
Maerl beds are formed by the accumulation of free-living coralline algae and have considerable ecological significance due to the high diversity of associated fauna and flora. The rapid expansion of the Atlantic salmon Salmo salar aquaculture industry in Norway may have major impacts on surrounding maerl beds through the release of effluents, including fish faeces. This study is the first to test the effects of salmon faeces and inorganic sediment deposition on the photosynthesis, respiration, calcification and pigment content of the coralline alga Lithothamnion soriferum. In a 6 wk laboratory experiment, inorganic sediment and salmon faeces deposition significantly reduced the amount of light reaching the surface of coralline algae. No impact of inorganic sediment deposition was detected on L. soriferum physiology, while salmon faeces deposition increased respiration rate and reduced net primary production and calcification. The accumulation of salmon faeces stimulates proliferation of bacteria, with adverse consequences on L. soriferum physiology due to the potential release of toxic compounds. Burial by salmon faeces deposition also affects the physiology of coralline algae due to the flocculation of sticky faeces particles, which may limit nutrient and gas exchanges in the vicinity of thalli. Carbon dioxide accumulation in the vicinity of $L$. soriferum may lead to a decline in $\mathrm{pH}$ and alter the calcification process in cell walls. In natural maerl beds, the negative effect of faeces deposition may be exacerbated by longer-term exposure and the presence of other chemicals released by fish farms.
\end{abstract}

KEY WORDS: Salmon faeces · Coralline algae · Photosynthesis · Calcification · Inorganic sediment $\cdot$ Maerl $\cdot$ Lithothamnion soriferum

\section{INTRODUCTION}

Since capture fishery production has been relatively static for the past $40 \mathrm{yr}$, aquaculture has been responsible for the impressive growth in the supply of fish for human consumption (FAO 2020). Projections for 2030 estimate that $59 \%$ of fish for human consumption will come from the aquaculture industry, compared to $52 \%$ in 2018 (FAO 2020). Today, about $69 \%$ of the world's salmon harvest is farmed, with $7 \%$ annual growth in the period 2010-2019 (Mowi 2020). The clear and

\footnotetext{
${ }^{*}$ Corresponding author: erwann.legrand@hi.no
}

sheltered cool waters provided by Norwegian fjords are well suited for farming salmon. Norway has thus developed an extensive salmonid aquaculture and represents the major salmon farming industry in Europe, with an annual production of ca. 1.3 Mt in 2019. This is an increase of ca. $320 \%$ over the last $20 \mathrm{yr}$ (https://www.fiskeridir.no) and is likely to continue in the future to meet the food demand of a growing global population.

The rapid expansion of the salmon aquaculture industry in Norway can have major impacts on surrounding benthic ecosystems due to the release of 
considerable amounts of effluents, including dissolved nutrients, organically rich waste feed and faeces, antiparasitic therapeutants and antifouling compounds (Carroll et al. 2003, Burridge et al. 2010, Haugland et al. 2019). Organic enrichment of the seabed is a widely encountered impact of salmon farming (Iwama 1991, Karakassis et al. 2000). During the on-growth of Atlantic salmon Salmo salar L. in open net cages, a large amount of organic wastes (faeces and waste food pellets) is released, sinks to the seafloor and interacts with benthic ecosystems. Sedimentation rates vary greatly depending on farm size, environmental characteristics (such as depth and current velocity), distance to the farm and production cycle (Keeley et al. 2013, 2019). Deposition rates of $10-20 \mathrm{~g}$ dry weight [DW] $\mathrm{m}^{-2} \mathrm{~d}^{-1}$ have been measured in the immediate vicinity of a mid-sized Norwegian farm at a deep-water location (Kutti et al. 2007). Salmon farms operating in dynamic water, such as shallow coastal areas, can produce comparatively more diffuse footprints on benthic ecosystems (Broch et al. 2017). Keeley et al. (2019) reported deposition of organic wastes up to $600 \mathrm{~m}$ away from the cages. Deposition rates up to $70 \mathrm{~g} \mathrm{DW} \mathrm{m}^{-2} \mathrm{~d}^{-1}$ were measured in the vicinity of a farm in a shallow location, with high production levels (Keeley et al. 2019). A severe impact of intensive production farms is generally associated with poor currents and water circulation, which may drastically damage benthic ecosystems due to the lack of oxygen in the sediment (Soto \& Norambuena 2004, Yakushev et al. 2020). The protection of vulnerable ecosystems is of major concern and farms are now monitored regularly to assess their impacts on the surrounding environment. However, current methods used for monitoring have been developed for deeper soft-sediment environments and may therefore not be suitable to detect subtle and slowly evolving impacts on maerl beds.

Maerl beds, also called rhodolith beds, have a global distribution and are formed by the accumulation of non-geniculate coralline algae. Coralline algae species forming maerl beds have a perennial life strategy and can be long-lived ( $>100 \mathrm{yr}$ ), with extremely slow growth rates (Potin et al. 1990, Blake \& Maggs 2003, Steller et al. 2003, Frantz et al. 2005). As coralline algae require light for photosynthesis and growth, the depth of maerl beds is determined by water turbidity. Therefore, they usually occur from the lower shore to $40 \mathrm{~m}$ (Hall-Spencer et al. 2010), although some tropical maerl beds can range down to $270 \mathrm{~m}$ deep in very clear waters (RiosmenaRodriguez et al. 2016). Water motion is also a key factor determining the growth and distribution of coralline algae. They require moderate-to-strong seabed currents to sweep away mud particles and to prevent burial by sediment and silt smothering (HallSpencer 1998, Marrack 1999, Wilson et al. 2004, Coletti et al. 2016). As bioengineers, maerl beds provide a 3-dimensional habitat for associated species (Nelson 2009) and have considerable ecological significance due to the high diversity of associated organisms (Hall-Spencer 1998, Barbera et al. 2003, Peña et al. 2014). They also harbour high densities of broodstock bivalves and act as nursery areas for the juvenile stages of commercial species (Hall-Spencer 1998, Kamenos et al. 2004). Maerl beds are listed as a threatened and declining habitat by the Oslo-Paris Convention (OSPAR; Hall-Spencer et al. 2010).

Maerl beds are currently affected by a wide range of environmental changes induced by human activities and require tight management controls (HallSpencer 1998). Over the past $20 \mathrm{yr}$, many studies have confirmed the negative effect of climate change on maerl-forming species, both through in situ approaches and laboratory experiments (Martin \& Gattuso 2009, Cornwall et al. 2019). In addition, maerl bed structure and functioning are affected by a growing number of local anthropogenic pressures, such as Coquereau et al. 2017, Bernard et al. 2019), maerl extraction (Grall \& Hall-Spencer 2003), sewage discharge (Grall \& Glémarec 1997) and aquaculture (Steller et al. 2003, Wilson et al. 2004, Hall-Spencer et al. 2006, Sanz-Lázaro et al. 2011, Aguado-Giménez \& Ruiz-Fernández 2012).

The release of large amounts of fish faeces by aquaculture is likely to be particularly damaging for maerl beds through smothering with organic-rich discharged faeces (Grall \& Hall-Spencer 2003). Waste particles settle in the vicinity of cages and become trapped within a complex structure of coralline algae, rather than being resuspended and dispersed (Hall-Spencer et al. 2006). Significant reductions in the associated biodiversity of maerl beds have already been linked to organic enrichment from salmon fish farms in Scotland (Hall-Spencer et al. 2006). In addition to the loss of diversity, organic enrichment from fish farms may affect the functioning of maerl beds by altering the physiology of maerl-forming species. Fish faeces deposition may reduce light available for photosynthesis and growth of underlying coralline algae and increase the oxygen demand due to the growth of sulphur-reducing bacteria degrading organic carbon (Brooks et al. 2002, Wilson et al. 2004). The presence of bacteria degrading the deposited organic matter may also exacerbate the negative effect of faeces deposition on coralline 
algae by reducing oxygen availability and gas exchange in the vicinity of thalli.

Currently, the effect of fish faeces deposition from aquaculture on the physiological response of freeliving coralline algae remains poorly documented. We conducted a 6 wk laboratory experiment to better understand the influence of ecologically relevant levels of salmon faeces deposition on the photosynthesis, respiration, calcification and pigment content of the free-living coralline alga Lithothamnion soriferum Kjellman, 1883. L. soriferum was previously described under the name $L$. erinaceum (Melbourne et al. 2017), but recent DNA sequencing from different Arctic and Subarctic Lithothamnion species revealed that $L$. soriferum is the correct name for this taxon (Peña et al. 2021).

\section{MATERIALS AND METHODS}

\subsection{Sample collection}

Lithothamnion soriferum thalli were collected from 10 m depth in Skårasund, Vestland County, Norway, $\left(60^{\circ} 8^{\prime} 30^{\prime \prime} \mathrm{N}, 5^{\circ} 9^{\prime} 56^{\prime \prime} \mathrm{E}\right)$ using a naturalist dredge (width: $0.5 \mathrm{~m}$; height: $0.5 \mathrm{~m}$; net: $1 \mathrm{~m}$ long). Selected thalli were fully alive (pink colour on the whole thallus). Samples were transported to the Institute of Marine Research (IMR) Austevoll Station and cleaned of epiphytes. L. soriferum thalli were randomly assigned to 12 flow-through aquaria (15 l capacity; $90 \mathrm{~g}$ per aquarium) and acclimated for $2 \mathrm{wk}$ at ambient temperature $\left(8.8 \pm 0.2^{\circ} \mathrm{C}[\mathrm{SD}]\right)$ and salinity $(34.8 \pm 0.1)$.

\subsection{Salmon faeces and inorganic sediment}

About $5 \mathrm{~kg}$ of dry salmon faeces were collected from Bioretur (Indre Arna, Vestland, Norway), a processing plant that receives aquaculture faecal waste from closed and land-based fish farms. The drying process was performed using the Fishsludge Recovery System ${ }^{\circledR}$ (https://bioretur.no). No chemicals were used during this process. Dry faeces were transported to Austevoll Station and sieved trough 100 and $400 \mu \mathrm{m}$ sieves. Only particles between 100 and $400 \mu \mathrm{m}$ were selected for the experiment. Desired particle size was determined prior to the experiment in order to have quick sedimentation $(>100 \mu \mathrm{m})$ and avoid flocculation in pipes during the experiment $(<400 \mu \mathrm{m})$. Particle size in this experiment is consistent with observations made at an active salmon aquaculture site (Law et al. 2014). Dried faeces were stored in the freezer at $-20^{\circ} \mathrm{C}$ pending their use for the experiment.

Inorganic sediment was collected from a producer of artificial sand (Fana Stein) and was composed of crushed granite rock. As sediment grain size influences the biological characteristics of coralline algae (Bordehore et al. 2003), the sand was also sieved and particles between 100 and $400 \mu \mathrm{m}$ were selected for the experiment. Collected sand was burned for $6 \mathrm{~h}$ at $550^{\circ} \mathrm{C}$ to prevent bacterial activity. Dry inorganic sediment was stored in the freezer at $-20^{\circ} \mathrm{C}$ pending its use for the experiment.

\subsection{Experimental setup}

L. soriferum thalli were exposed to 3 different treatments: (1) control, (2) inorganic sediments, (3) salmon faeces, with 4 replicates in each treatment for 6 wk (25 March to 5 May 2019; Fig. 1). Each experimental tank was continuously supplied with natural deep seawater (pumped in front of Austevoll Station at a depth of $160 \mathrm{~m}$ ), at a flow rate of $20 \mathrm{l} \mathrm{h}^{-1}$. Inorganic sediment and salmon faeces were added throughout the experiment using 2 header tanks (80 l each; 1 per treatment) and peristaltic pumps. Each peristaltic pump had a flow rate of $0.4 \mathrm{l} \mathrm{h}^{-1}$. The 2 header tanks were filled with new seawater every day. Dry inorganic sediment or dry salmon faeces were added to seawater, depending on the treatment. Circulating pumps were used in header tanks in order to keep particles in suspension. Desired concentration of salmon faeces particles in header tanks was determined prior to the experiment in order to have a depositional flux of $15 \mathrm{~g} \mathrm{~m}^{-2} \mathrm{~d}^{-1}$ in each tank. This flux is in accordance with the total particulate matter depositional flux measured by Keeley et al. (2019) between 100 and $200 \mathrm{~m}$ distance from a highcapacity farm (annual production of ca. $9000 \mathrm{t}$ of fish), during mid-production (31-40 m deep). Depositional flux for inorganic sediment was estimated in order to have a similar number of particles deposited as used for salmon faeces treatment (particle size was similar between these 2 treatments, i.e. 100-400 $\mu \mathrm{m}$, but particle mass differed). We estimated the number of particles in $1 \mathrm{~g}$ of dry faeces using a microscope and a counting cell and compared it to the number of particles in $1 \mathrm{~g}$ of dry sediment. Calculated depositional flux for inorganic sediment was $45 \mathrm{~g} \mathrm{~m}^{-2} \mathrm{~d}^{-1}$. Salmon faeces and inorganic sediment depositional fluxes were monitored during the experiment using petri dishes, arranged at the bottom of each tank. 


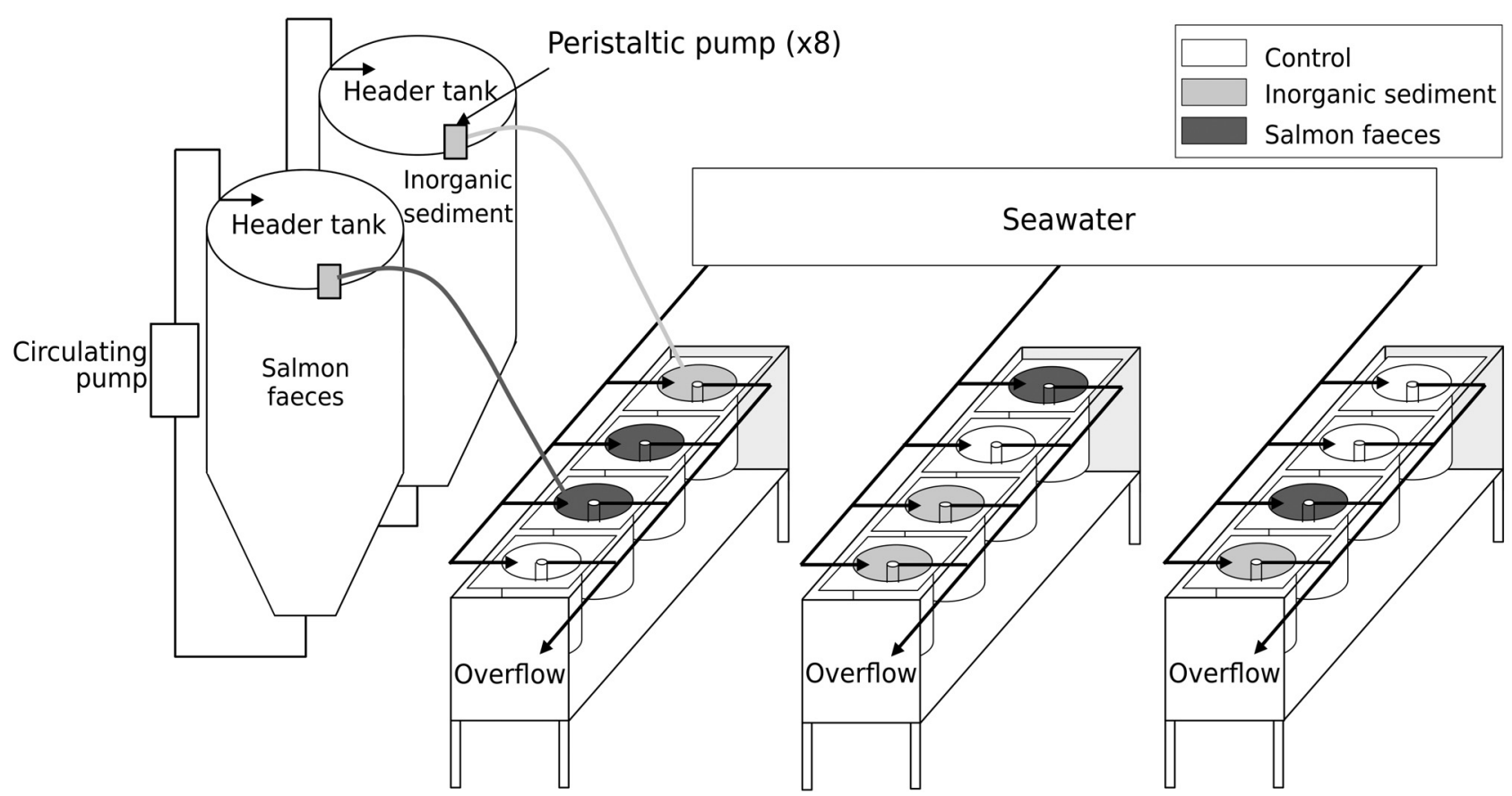

Fig. 1. Experimental setup composed of $15 \mathrm{ltanks}(\mathrm{n}=12)$ supplied with natural deep seawater. Four replicates were used for each treatment (control, inorganic sediment, salmon faeces). Inorganic sediment and salmon faeces were added using two 801 header tanks (1 per treatment) and peristaltic pumps

Every $2 \mathrm{~d}$, salmon faeces and inorganic sand were collected in petri dishes using a syringe and filtered through pre-weighted GF/F filters (pore size: $0.7 \mu \mathrm{m}$; diameter: $47 \mathrm{~mm})$. Peristaltic pump rates were adjusted to maintain depositional fluxes of 15 and $45 \mathrm{~g}$ $\mathrm{m}^{-2} \mathrm{~d}^{-1}$ for salmon faeces and inorganic sediment treatments, respectively.

Average irradiance reaching the bottom of each tank was $40 \mu \mathrm{mol}$ photons $\mathrm{m}^{-2} \mathrm{~s}^{-1}$ (before particles were added to the system). Light was provided by $36 \mathrm{~W}$ fluorescent tubes $(\mathrm{n}=4$; Lumilux), with a light: dark photoperiod of 14:10 h. Irradiance ( $\mu \mathrm{mol}$ photons $\mathrm{m}^{-2} \mathrm{~s}^{-1}$ ) was checked once a week in each aquarium using a photosynthetically active radiation sensor (LI-190R quantum cosine-corrected sensor coupled to a LI-250A light meter; LI-COR). At the beginning of the experiment, HOBO loggers (Onset) were placed on the bottom of 3 aquaria per treatment, in order to measure light reduction induced by inorganic sediment and salmon faeces deposition. Light level was automatically measured every $30 \mathrm{~min}$ throughout the experiment. Results were averaged per treatment and per day, and light level was expressed as percentage of initial irradiance (initial irradiance $=40 \mu \mathrm{mol}$ photons $\mathrm{m}^{-2} \mathrm{~s}^{-1}$ ). Measured light level was considered the proportion of initial irradiance reaching the tank bottom. Temperature and salinity were recorded daily in each tank (LabQuest ${ }^{\circledR} 2$ multimeter, Vernier).

\subsection{Photosynthesis and respiration rates}

After 6 wk of exposure, thalli were incubated in $600 \mathrm{ml}$ rectangular chambers (width: $5 \mathrm{~cm}$, length: $15 \mathrm{~cm}$, height: $15 \mathrm{~cm}$ ) to determine net photosynthetic rate (i.e. oxygen production under ambient irradiance, $40 \mu \mathrm{mol}$ photons $\mathrm{m}^{-2} \mathrm{~s}^{-1}$ ) and respiration rate (i.e. oxygen uptake in the dark). Inorganic sediment and salmon faeces inputs in tanks were stopped $24 \mathrm{~h}$ prior to incubations. On the day before each incubation, thalli were gently cleaned using a smooth brush and rinsed using a syringe. Sediment and faeces were thus removed, as well as epiphytes which may have grown during the experiment. About $20 \mathrm{~g}$ of coralline algae, randomly selected within each experimental tank, were placed on the bottom of the incubation chambers. Chambers were filled with the same natural seawater, and a magnetic stirrer was used to prevent oxygen gradients. Background respiration was measured in control chambers filled only with natural seawater. Three incubations were performed for each experimental tank, both in the light and in the dark, and results 
were averaged per tank. Incubations lasted approximately $5 \mathrm{~h}$ in the light and $3 \mathrm{~h}$ in the dark in order to keep oxygen saturation above $80 \%$. Oxygen concentration was measured in each chamber every $2 \mathrm{~s}$, using an optical fiber system (OXY-4 SMA ${ }^{\circledR}$, PreSens). Immediately after incubation, the volume of seawater was determined for each incubation chamber. Thalli were collected, dried at $60^{\circ} \mathrm{C}$ for $48 \mathrm{~h}$ and weighed to obtain DW. In each tank, thalli that were not used for incubation were frozen at $-80^{\circ} \mathrm{C}$ pending chlorophyll a ( $\mathrm{chl}$ a) and carotenoid pigment extractions.

Net primary production (NPP; $\mu$ mol $\mathrm{O}_{2} \mathrm{gDW}^{-1} \mathrm{~h}^{-1}$ ) and respiration $(R$, expressed as oxygen consumption rate; $\mu \mathrm{mol} \mathrm{O}_{2} \mathrm{gDW}^{-1} \mathrm{~h}^{-1}$ ) were calculated as the regression coefficient of the linear increase or decrease in oxygen concentration, respectively, in seawater of the chambers. NPP and $R$ were calculated using the package 'respR' (Harianto et al. 2019) in the software $\mathrm{R}$ version 3.5.2 (R Core Team 2020), according to Eq. (1). Changes in oxygen concentration in control chambers were used for background corrections of NPP and $R$ rates:

$$
\mathrm{NPP} \text { or } R=\frac{\Delta \mathrm{O}_{2} \times \mathrm{V}}{\Delta t \times \mathrm{DW}}
$$

where $\Delta t$ is the duration between the first and the last point of the linear regression (h), $\Delta \mathrm{O}_{2}$ the difference in oxygen concentration between the first and the last point of the linear regression $\left(\mu \mathrm{mol} \mathrm{O}_{2} \mathrm{l}^{-1}\right), \mathrm{V}$ is the volume (l) of seawater in the chamber, and DW is the dry weight $(\mathrm{g})$ of incubated thalli.

Gross primary production (GPP; $\mu \mathrm{mol} \mathrm{O}_{2} \mathrm{gDW}^{-1}$ $\mathrm{h}^{-1}$ ) was calculated following Eq. (2):

$$
\mathrm{GPP}=\mathrm{NPP}+|R|
$$

\subsection{Pigment extraction}

Chl $a$, carotenoid and phycobiliproteins (allophycocyanin $[\mathrm{APC}]$, phycocyanin $[\mathrm{PC}]$, phycoerythrin[PE]) pigment extractions were performed on 4 thalli per tank, and results were averaged per tank. Three fragments were taken from each thallus, freeze-dried and crushed together into a powder using a cold mortar, in the dark. For chl a and carotenoid pigment extractions, about $0.15 \mathrm{~g}$ of powder was precisely weighted, suspended in $10 \mathrm{ml}$ of $90 \%$ acetone and stored in the dark at $4^{\circ} \mathrm{C}$ for $12 \mathrm{~h}$. Samples were centrifuged at $1792 \times g\left(4^{\circ} \mathrm{C}\right.$ for $\left.5 \mathrm{~min}\right)$, the supernatant was collected, and the absorbance was measured at 470,630, 647, 664 and $691 \mathrm{~nm}$.
Chl $a$ and carotenoid concentrations ( $\mu \mathrm{g} \mathrm{gDW}^{-1}$ ) were obtained from Ritchie (2008) and Torres et al. (2014), following Eqs. (3) and (4):

$$
\text { Chl } a=
$$

$\frac{\left(-0.3319 A_{630}-1.7485 A_{647}+11.9442 A_{664}-1.4306 A_{691}\right) \times \mathrm{V}}{\mathrm{mp}}$

$$
\text { Carotenoids }=\frac{\left(1000 A_{470}-2.77 \times \mathrm{Chl} \mathrm{a}\right) \times \mathrm{V}}{\mathrm{mp} \times 213}
$$

where $\mathrm{V}$ is the volume $(\mathrm{ml})$ of acetone, and $\mathrm{mp}$ is the mass $(\mathrm{g})$ of powder used for the extraction.

For phycobiliprotein pigment extractions, about $0.15 \mathrm{~g}$ of powder was precisely weighted and suspended in $10 \mathrm{ml}$ of phosphate potassium buffer $\left(0.1 \mathrm{M}, \mathrm{pH} 6.8\right.$; precooled at $\left.4^{\circ} \mathrm{C}\right)$. Samples were maintained on ice for $2 \mathrm{~h}$ at $4^{\circ} \mathrm{C}$ and then centrifuged at $1792 \times g\left(4^{\circ} \mathrm{C}\right.$ for $\left.5 \mathrm{~min}\right)$. The supernatant was collected, and absorbance was measured in the spectrophotometer at 498.5, 614.0 and $651.0 \mathrm{~nm}$. APC, PC and PE concentrations ( $\mu \mathrm{g} \mathrm{gDW}^{-1}$ ) were obtained following Eqs. (5), (6) and (7), respectively (Kursar et al. 1983):

$$
\begin{gathered}
\mathrm{APC}=\frac{\left(181.3 A_{651}-22.3 A_{614}\right) \times \mathrm{V}}{\mathrm{mp}} \\
\mathrm{PC}=\frac{\left(151.1 A_{614}-99.1 A_{651}\right) \times \mathrm{V}}{\mathrm{mp}} \\
\mathrm{PE}=\frac{\left(155.8 A_{498.5}-40.0 A_{614}-10.5 A_{651}\right) \times \mathrm{V}}{\mathrm{mp}}
\end{gathered}
$$

where $\mathrm{V}$ is the volume $(\mathrm{ml})$ of buffer, and $\mathrm{mp}$ is the mass $(g)$ of powder used for the extraction.

\subsection{Net calcification rate}

At the beginning of the experiment, 1 thallus was selected per tank and tagged using nylon string. Four replicates were used per treatment. Selected thalli were of similar size and were buoyant-weighed according to the technique of Davies (1989). Individual buoyant weights of the thalli were determined by suspending them in a beaker filled with filtered seawater. They were suspended by a nylon string attached to a high-precision balance (Kern \& Sohn, ABT320-4NM $\pm 0.1 \mathrm{mg}$ ). Water density was determined by weighing an inert reference object (glass stopper) of known air weight and density, in the seawater (Davies 1989). The buoyant weight method assumes that the density of organic tissues is close to that of seawater, and this technique is used to measure crustose coralline algae skeletal weight (Steller et al. 2007). This method has also been used with other marine calcifiers such as corals (Davies 1989) 
and other free-living coralline algae species (e.g. Phymatolithon lusitanicum, Sordo et al. 2020). Since L. soriferum growth depends on calcium carbonate $\left(\mathrm{CaCO}_{3}\right)$ deposition, net calcification rate was estimated for each thallus by measuring the change in buoyant weight between the beginning and the end of the experiment. For more accuracy, each thallus was weighted 3 times, and calculations were made on the average of the 3 measurements. The change in buoyant weight was converted to DW, considering the density of $\mathrm{CaCO}_{3}\left(2.71 \mathrm{~g} \mathrm{~cm}^{-3}\right.$; Steller et al. 2007). Calcification rate was normalized to thalli DW and days of growth during the experiment $\left(\mu \mathrm{mol} \mathrm{CaCO}_{3}\right.$ $\left.\mathrm{gDW}^{-1} \mathrm{~d}^{-1}\right)$.

\subsection{Statistical analysis}

Assumptions of normality (Shapiro test) and homogeneity of variances (Bartlett test) were tested prior to analyses. All statistical analyses were carried out using the software $\mathrm{R}$ version 3.5.2 (R Core Team 2020).

In order to statistically compare the temperature in the different treatments, results from 30 min time intervals were averaged per day. The Kruskal-Wallis test was used to examine the differences in light and temperature conditions between treatments. When the Kruskal-Wallis test showed significant results, a post hoc Dunn test was applied to identify differences among treatments with a confidence level of $95 \%$.

The effect of experimental treatments on NPP, GPP, $R$, net calcification rate and pigment content was tested with a 1-way ANOVA, considering 4 replicates per treatment. Differences among treatments were explored with Tukey's HSD post hoc comparisons with a confidence level of $95 \%$.

\section{RESULTS}

\subsection{Temperature and light conditions}

No significant differences in temperature were detected between treatments (Kruskal-Wallis, p = 0.71). Temperature and salinity remained stable throughout the experiment $\left(8.9 \pm 0.3^{\circ} \mathrm{C}\right.$ and $34.8 \pm$ 0.1 , respectively; $\pm \mathrm{SD}$ ). Light level differed significantly between treatments (Kruskal-Wallis, p < 0.001). Measured light levels in the control condition remained stable throughout the experiment (Fig. 2). In contrast, a significant decline in light level, about $60 \%$, was detected with sediment and faeces deposi-

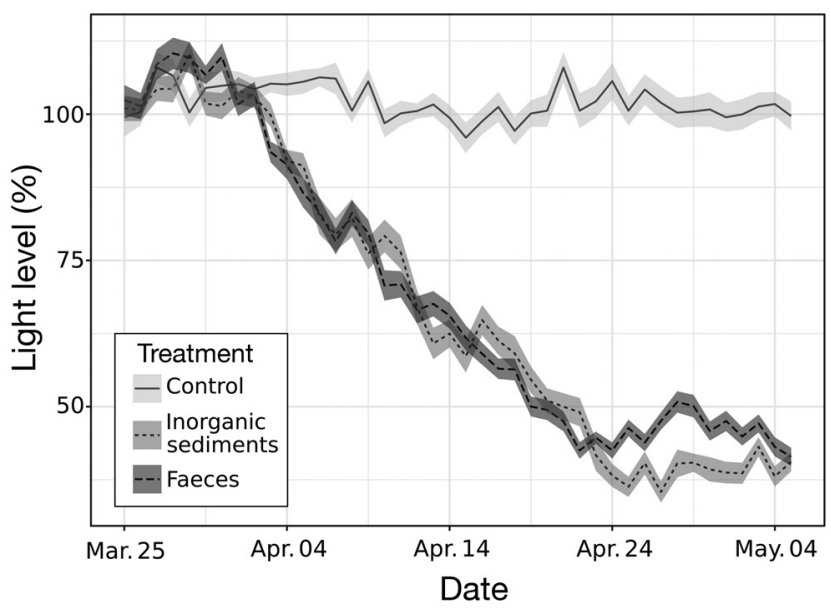

Fig. 2. Evolution of light levels during the experiment (expressed as percentage of initial irradiance; initial irradiance = $40 \mu \mathrm{mol}$ photons $\mathrm{m}^{-2} \mathrm{~s}^{-1}$ ) in the 3 treatments (control, inorganic sediment, salmon faeces). Lines represent daily mean light level throughout the experiment, and shaded parts show $\mathrm{SE}(\mathrm{n}=84)$

tion, compared to the control (Dunn test; $\mathrm{p}<0.001$ ). However, no significant difference was detected between inorganic sediment and faeces treatments (Dunn test; $\mathrm{p}=0.70$ ).

\subsection{Photosynthesis, respiration and calcification}

NPP was significantly affected by experimental treatment (1-way ANOVA; $F=6.20, \mathrm{p}=0.020$; Fig. 3a). No significant difference was observed between control and inorganic sediment treatments (0.43 and $0.40 \mu \mathrm{mol} \mathrm{O}_{2} \mathrm{gDW}^{-1} \mathrm{~h}^{-1}$, respectively; Tukey's HSD; $\mathrm{p}=0.87$ ), whereas salmon faeces deposition induced a decline in NPP of $41 \%$, compared with the control condition (Tukey's HSD; $\mathrm{p}=0.024$ ). Mean GPP varied from $0.49 \mu \mathrm{mol} \mathrm{O} \mathrm{gDW}^{-1} \mathrm{~h}^{-1}$ (faeces treatment) to $0.58 \mu \mathrm{mol} \mathrm{O} \mathrm{gDW}^{-1} \mathrm{~h}^{-1}$ (control; Fig. 3b), but no significant effect of experimental treatment on GPP was detected (1-way ANOVA; $F=$ 2.48, $\mathrm{p}=0.14)$.

Lithothamnion soriferum $R$ ranged from $0.12 \mu \mathrm{mol}$ $\mathrm{O}_{2} \mathrm{gDW}^{-1} \mathrm{~h}^{-1}$ (inorganic sediment treatment) to 0.19 $\mu \mathrm{mol} \mathrm{O} \mathrm{gDW}^{-1} \mathrm{~h}^{-1}$ (faeces treatment; Fig. 3c). Experimental treatments significantly affected $R$ (1-way ANOVA; $F=11.64, \mathrm{p}<0.01)$. $R$ was similar between control and inorganic sediment treatments (Tukey's HSD; $\mathrm{p}=0.26$ ), but significantly increased under faeces treatment compared with control and inorganic sediment treatments (Tukey's HSD; $\mathrm{p}=0.032$ and $\mathrm{p}<$ 0.01 , respectively). 

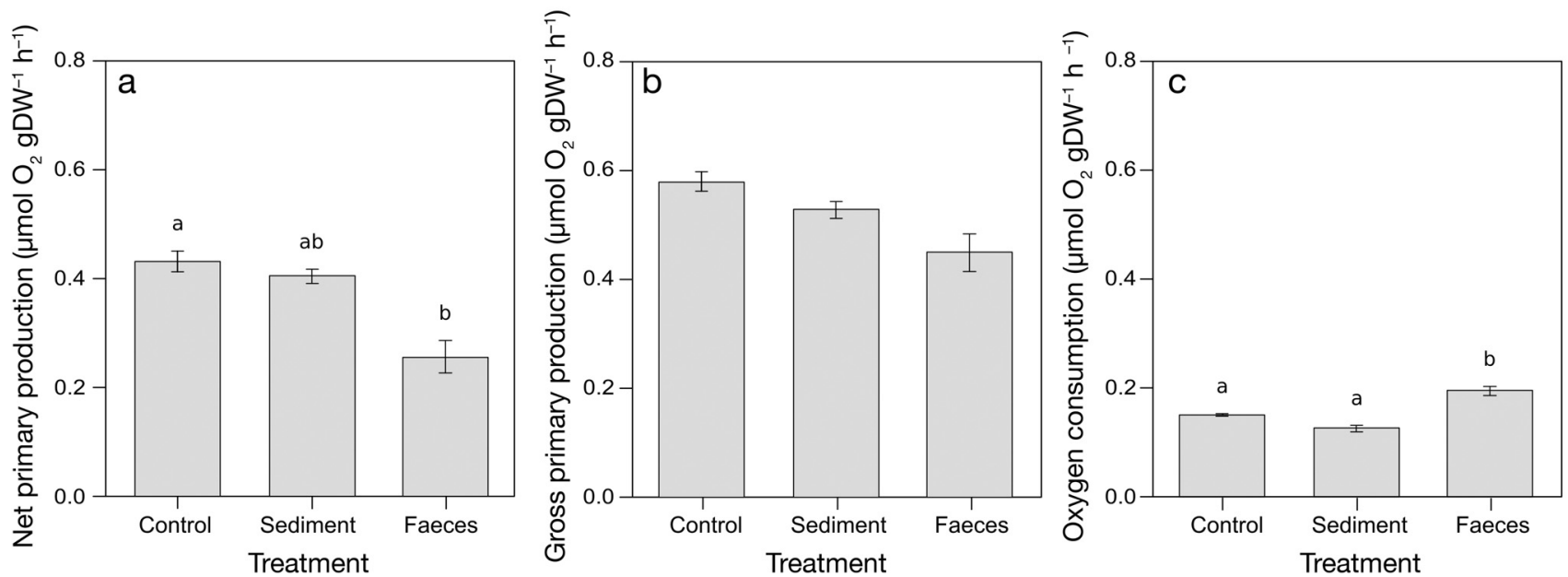

Fig. 3. Mean \pm SE (a) Net primary production, (b) gross primary production and (c) respiration rate (expressed as oxygen consumption) of Lithothamnion soriferum in control, inorganic sediment and salmon faeces treatments $(\mathrm{n}=4)$. Treatments with different letters are significantly different (Tukey's HSD test, $\mathrm{p}<0.05$ )

Chl a, carotenoid and phycobiliprotein pigment concentrations in the different treatments are presented in Table 1. Mean chl $a$ and carotenoid concentrations were 0.11 and $0.028 \mathrm{mg} \mathrm{gDW}^{-1}$, and mean APC, $\mathrm{PC}$ and PE concentrations were $0.070,0.060$ and $0.54 \mathrm{mg} \mathrm{gDW}^{-1}$, respectively. Inorganic sediment and salmon faeces deposition did not significantly affect the concentration of the different pigments (Table 1).

Net calcification rate was significantly affected by experimental treatments (1-way ANOVA; $F=7.58$, $\mathrm{p}=0.012$; Fig. 4). Higher calcification rate was measured under control and inorganic treatments $(0.55$ and $0.56 \mu \mathrm{mol} \mathrm{CaCO}_{3} \mathrm{gDW}^{-1} \mathrm{~d}^{-1}$ ). Faeces deposition greatly reduced $L$. soriferum net calcification rate, with a drop of $94 \%$ compared to other conditions $\left(0.035 \mu \mathrm{mol} \mathrm{CaCO} \mathrm{gDW}^{-1} \mathrm{~d}^{-1}\right.$; Tukey's HSD test, $\mathrm{p}<$ $0.05)$. On the other hand, no significant difference was detected between control and inorganic sediment conditions (Tukey's HSD test, $\mathrm{p}=0.995$ ).

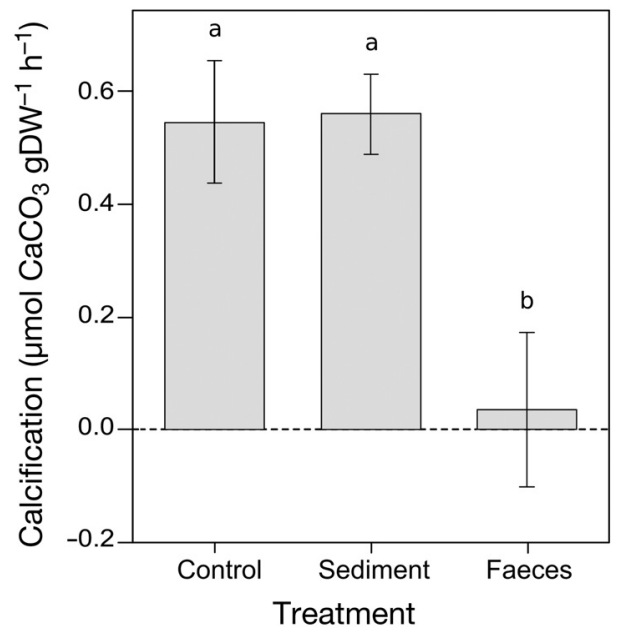

Fig. 4. Net calcification rate of Lithothamnion soriferum (mean $\pm \mathrm{SE}$ ) in control, inorganic sediment and salmon faeces treatments $(n=4)$. Treatments with different letters are significantly different (Tukey's HSD test, $\mathrm{p}<0.05$ )

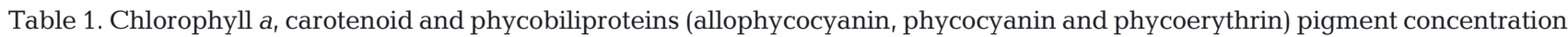
of Lithothamnion soriferum ( $\mathrm{mg} \mathrm{g}^{-1}$ dry weight) in control, inorganic sediment and salmon faeces treatments $($ mean \pm SE; $\mathrm{n}=4$ ) followed by results of 1-way ANOVA testing the effect of the experimental treatments on the concentration of each pigment

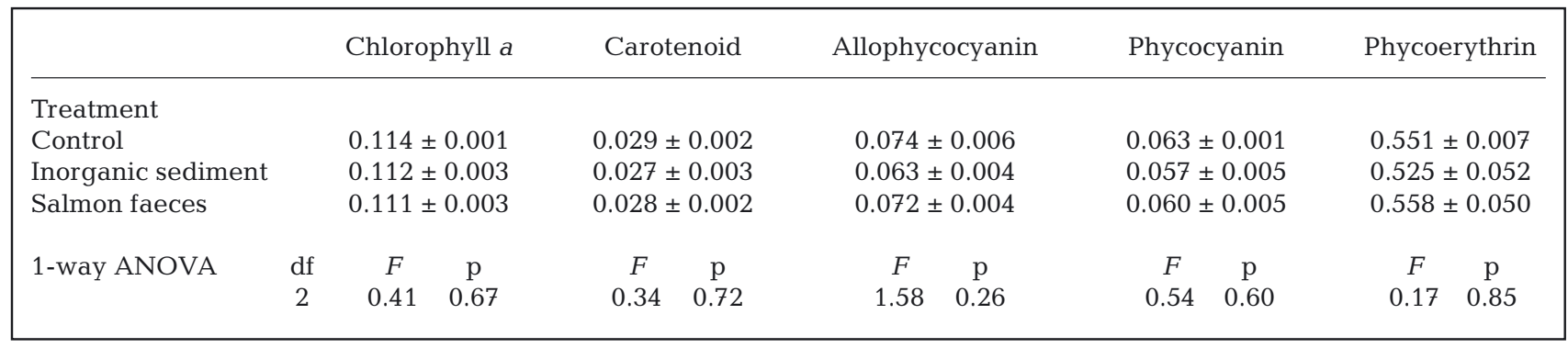




\section{DISCUSSION}

The present study is the first to show that salmon faeces deposition has a strong negative impact on the physiological response of Lithothamnion soriferum, resulting in clearly reduced net photosynthesis and growth, and enhanced respiration rates. Our results showed that both inorganic sediment and salmon faeces deposition significantly reduced the light level reaching the surface of coralline algae. Light reduction due to burial by sedimented particles represents a major disturbance to maerl beds. Several studies reported an increase in maerl mortality induced by fishing gears, especially dredges, due to the increase in suspended particles (Hall-Spencer \& Moore 2000, Hauton et al. 2003, Kamenos et al. 2003, Bernard et al. 2019). In situ observations made in the vicinity of Scottish fish farms also revealed that faeces particles settled on maerl beds and became trapped between branches and interstices of coralline algal thalli, rather than being resuspended (Hall-Spencer et al. 2006). Interestingly, in the present study we did not find a significant impact of inorganic sediment deposition on the physiology of $L$. soriferum, while salmon faeces deposition significantly increased $R$ and had a detrimental effect on NPP and calcification. A difference in the response of $L$. soriferum between inorganic sediment and salmon faeces treatments was observed even though light levels were similar between these 2 treatments, suggesting that sediment type is a more important factor than light reduction in explaining the physiological response of $L$. soriferum.

Many coralline algae are low-light adapted and can even survive periods of prolonged darkness (Roberts et al. 2002, Burdett et al. 2012, Sordo et al. 2020). In the coralline alga Phymatholithon calcareum, no deleterious effect was observed after being kept 4 wk in the dark, suggesting that this species is able to survive several months in the darkness (Wilson et al. 2004). In winter, maerl beds can survive during months under low light and temperature conditions and can cope with sporadic burial events caused by an increasing frequency of storms (Joshi et al. 2017). Moreover, higher temperature and light levels in spring and summer are associated with higher respiration, photosynthesis and calcification rates in coralline algae (Martin et al. 2006). Given that environmental conditions and energy requirements differ with seasons, we suggest that the vulnerability of $L$. soriferum to inorganic sediment and salmon faeces deposition may also change seasonally. As our experiment was carried out over only $6 \mathrm{wk}$, longer exposure to inorganic sediment could have more adverse consequences on the physiology of $L$. soriferum, and this effect may be accentuated with the incorporation of salmon faeces.

In order to cope with natural changes in irradiance, coralline algae can modulate their photosynthetic pigment content (Kim et al. 2013, Stengel et al. 2014). Sordo et al. (2020) highlighted reduced phycocyanin and phycoerythrin concentrations of the coralline alga $P$. lusitanicum in winter, when temperature and irradiance were low. Diurnal variations in phycocyanin concentration have also been observed in Ellisolandia elongata in a short-term experiment (Stengel et al. 2014). In contrast, our results did not show differences in the photosynthetic pigment content of $L$. soriferum between treatments despite the $60 \%$ decrease in light due to inorganic sediment and salmon faeces deposition. Coralline algae exhibit a wide range of responses, and further long-term studies are necessary to understand the effect of environmental conditions on the concentration of photosynthetic pigments (Pereira et al. 2012, Stengel et al. 2014, Sordo et al. 2020). In our experiment, cleaning thalli and removing inorganic sediment and salmon faeces $1 \mathrm{~d}$ before incubations may have allowed algae to modify their pigment content and may explain the lack of difference between treatments.

Physical and chemical parameters other than light reduction may explain the negative impact of salmon faeces deposition on the physiological response of L. soriferum. Discharges from aquaculture significantly enhance vertical flux and lead to shifts in the composition of organic material in sediments below cages, which stimulates the growth of sulphur-reducing bacteria in the vicinity of fish farms (Brooks et al. 2002, White et al. 2017). The increase in bacterial biomass in farm-associated sediments has been evidenced in several studies (La Rosa et al. 2004, Castine et al. 2009, Kawahara et al. 2009, Sweetman et al. 2014, White et al. 2017) and is commonly used as visual indicator of organic pollution from finfish aquaculture (Crawford et al. 2001, Brooks et al. 2004, Hamoutene et al. 2016). In the present experiment, salmon faeces were dried beforehand, which may have altered their chemical composition by removing some of the organic matter, phosphates and ammonia present in the faeces (Fishsludge Recovery System ${ }^{\circledR} ;$ Bioretur). Therefore, the processes involved in bacterial growth may differ between the laboratory and the field. However, despite the use of dry salmon faeces, we observed the growth of abundant bacterial mats in the salmon faeces treatment (Fig. 5).

Wilson et al. (2004) suggested that burial by a layer of fish faeces containing toxic compounds resulting 

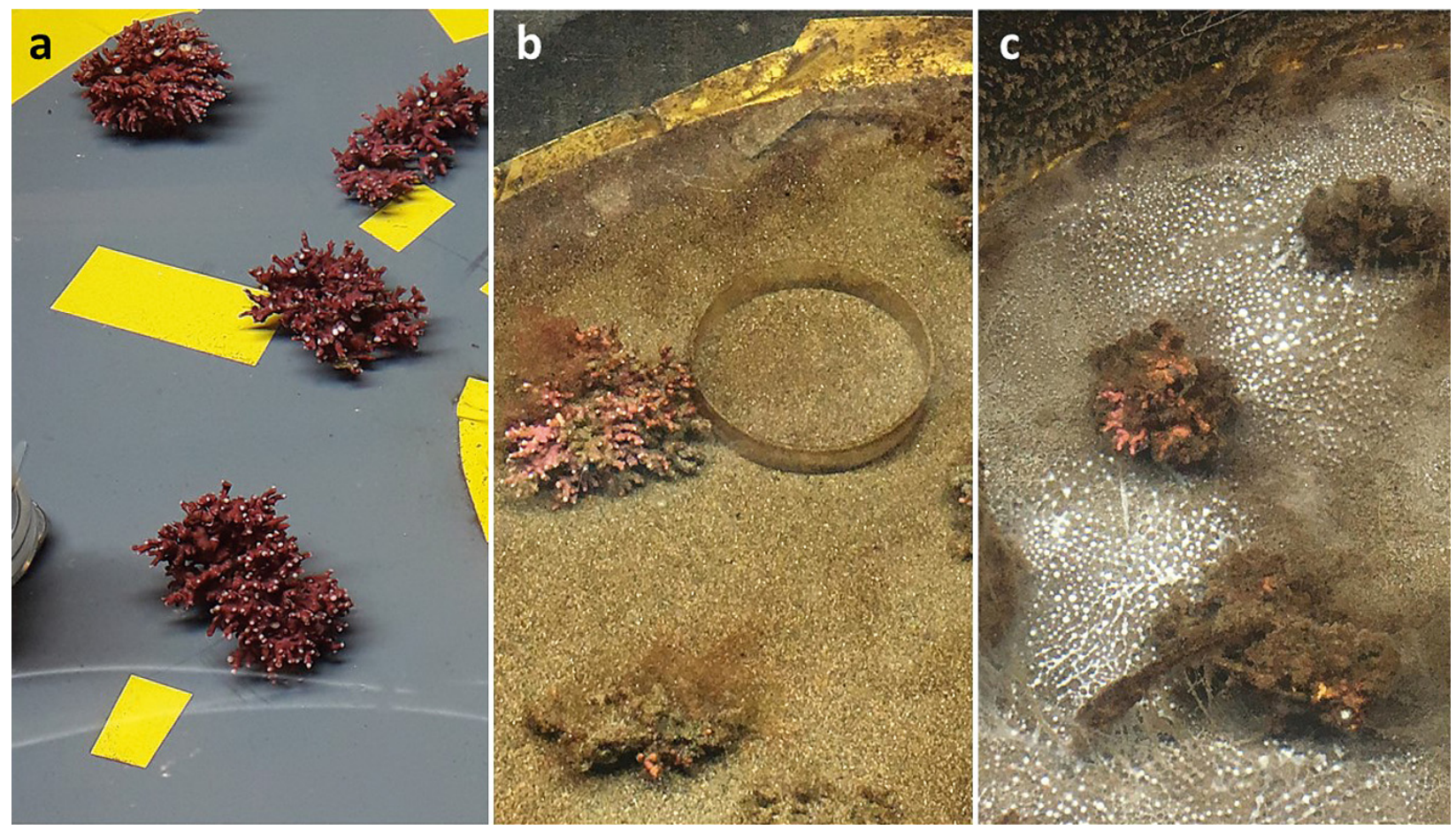

Fig. 5. Three experimental tanks with Lithothamnion soriferum after 6 wk exposure to (a) control, (b) inorganic sediment and (c) salmon faeces treatments

from bacterial activity, such as hydrogen sulphide, may be detrimental for the photosynthetic capacity of P. calcareum. In Brittany, France, major damage has also been observed on maerl beds, caused by high densities of the invasive gastropod Crepidula fornicata and the accumulation of its faeces and pseudofaeces (Chauvaud et al. 2000, Grall \& Hall-Spencer 2003). This is consistent with the results obtained in the present study, as salmon faeces deposition reduced both photosynthetic and calcification rates of $L$. soriferum. The presence of sulphur-reducing bacteria degrading organic carbon also reduces oxygen concentration in sediments (Blackburn et al. 1988, Holmer \& Kristensen 1992). Therefore, the higher respiration rate measured in the faeces treatment in our study likely occurred in response to the increased oxygen demand.

As an energy-demanding process, calcification relies on photosynthesis to provide the energy necessary to support the formation of a carbonate skeleton (Vásquez-Elizondo \& Enríquez 2016). The decline in photosynthesis, combined with enhanced energy demand induced by faeces deposition, had a negative impact on calcification rate. In addition, chemical processes occurring in the vicinity of thalli may exacerbate the decline in calcification rate. Macroalgae are able to modify their immediate chemical microenvironment near their surface via metabolic processes within their boundary layer (Hurd et al. 2011). Water movement over their surfaces has the effect of breaking down gradients of nutrients and favour gas exchange by reducing the boundary layer thickness (Hurd 2000). In L. soriferum, burial by inorganic sediment and salmon faeces deposition may reduce flow velocity in the vicinity of thalli, increasing the diffusive boundary layer thickness and limiting nutrient and gas exchanges (Wilson et al. 2004). This effect is likely to be more adverse with salmon faeces deposition due to the flocculation of faeces particles and the increased amount of sticky organic material (Law et al. 2014, Law \& Hill 2019). Furthermore, increased respiration of $L$. soriferum in the faeces treatment, combined with organic matter degradation by bacteria, likely reduced the boundary layer $\mathrm{pH}$ due to the accumulation of carbon dioxide. Carbon dioxide accumulation may lead to a decline in $\mathrm{pH}$, which can significantly alter the calcification process in cell walls and increase the dissolution of coralline algae (Short et al. 2015).

Respiration of coralline algae and bacteria also reduces oxygen concentration in the boundary layer, which may turn anoxic. Anoxia tolerance of coralline algae remains poorly understood but is likely to alter metabolic processes and their ability to survive such events in the longer term (Short et al. 2015). In Fucus 
serratus embryos, Chapman \& Fletcher (2002) found that burial in sediments leads to chemical alterations of the microenvironment in the immediate vicinity of the embryos and an accumulation of metabolic faeces products, detrimental for the growth and survival of embryos. Coralline algae could also be affected by processes occurring at the community level. Although our laboratory experiment provided critical information on the response of a single species under controlled conditions, field studies are required to obtain a better overview of the impact of fish farms on natural maerl beds. Nutrient enrichment due to the release of salmon faeces is likely to stimulate the activity of bioeroders, as evidenced in several studies on tropical coral reefs (Hallock 1988, Chazottes et al. 2002, 2017, Loya et al. 2004). This process may exacerbate the dissolution of coralline algae and have major implications on the structure and the functioning of maerl beds.

Given the massive expansion of salmonid aquaculture in Norway, there is an urgent need to improve procedures for risk assessment at aquaculture sites by taking into account maerl beds. Most of the industry's growth is planned in northern Norway, where most of the maerl beds are found. Our results showed that exposure to salmon faeces deposition have adverse consequences on the physiology of coralline algae. This impact results from a complex process, induced by both physical (light reduction, gas diffusion in the vicinity of thalli, increased in boundary layer thickness), biological (bacterial activity) and chemical (accumulation of toxic compounds such as hydrogen sulphide) factors. Natural maerl beds in the vicinity of fish farms are exposed to fish faeces deposition over longer periods, and more knowledge is needed about the longer-term effects. Other factors such as sea lice therapeutants, heavy metals and nutrient release may also act in concert with faeces deposition (Carroll et al. 2003, Burridge et al. 2010, Haugland et al. 2019) to increase the pressure on maerl beds.

To date, the amount of overlap between fish farms and maerl beds in Norway has not been determined, and coastal monitoring efforts are needed to fill the gap of knowledge on the distribution of this ecosystem (Taranger et al. 2015). Significant effects of fish farms have been recorded on maerl beds up to $100 \mathrm{~m}$ from farmed sites in Scotland (Hall-Spencer et al. 2006) and up to $200 \mathrm{~m}$ in a Western Mediterranean fish farm producing gilthead seabream and European seabass (Sanz-Lázaro et al. 2011). In Norway, farm sites generally have a maximal allowed production of salmon between 2340 and $4680 \mathrm{t} \mathrm{yr}^{-1}$ (Mowi 2020), which exceeds that of the Scottish and Mediterranean farms studied by Hall-Spencer et al. (2006)
(1272 t in 2013) and Sanz-Lázaro et al. (2011) (1000 t in 2006), respectively. Norwegian salmon fish farms are therefore likely to impact maerl beds over a larger area. The selection of sites for aquaculture facilities needs to consider avoiding emissions in the vicinity of maerl beds in order to preserve their structure and functioning. Pending further studies, we recommend that new farms be situated with at least $1 \mathrm{~km}$ distance from maerl beds.

Acknowledgements. We thank Cathinka Krogness, Florian Freytet and Stig Ove Utskot for the assistance provided in the lab; the station manager and staff at the Institute of Marine Research's Research station in Austevoll, Norway, for their help in monitoring the experiment; Thomas Sørlie Holden at UiB for boat support; Viviana Peña for help with Lithothamnion taxonomy; Bioretur AS for kindly providing the salmon faeces for our experiment; and the anonymous reviewers for their helpful comments on the manuscript. This study was financially supported by the Norwegian Ministry of Trade, Industry and Fisheries/Institute of Marine Research (Project no. 14900).

\section{LITERATURE CITED}

Aguado-Giménez F, Ruiz-Fernández JM (2012) Influence of an experimental fish farm on the spatio-temporal dynamic of a Mediterranean maërl algae community. Mar Environ Res 74:47-55

Barbera C, Bordehore C, Borg JA, Glémarec M and others (2003) Conservation and management of northeast Atlantic and Mediterranean maerl beds. Aquat Conserv 13:S65-S76

Bernard G, Romero-Ramirez A, Tauran A, Pantalos M, Deflandre B, Grall J, Grémare A (2019) Declining maerl vitality and habitat complexity across a dredging gradient: insights from in situ sediment profile imagery (SPI). Sci Rep 9:16463

Blackburn TH, Lund BA, Krom MD (1988) C- and N-mineralization in the sediments of earthen marine fishponds. Mar Ecol Prog Ser 44:221-227

Blake C, Maggs CA (2003) Comparative growth rates and internal banding periodicity of maerl species (Corallinales, Rhodophyta) from northern Europe. Phycologia 42:606-612

Bordehore C, Ramos-Esplá AA, Riosmena-Rodríguez R (2003) Comparative study of two maerl beds with different otter trawling history, southeast Iberian Peninsula. Aquat Conserv 13:S43-S54

Broch OJ, Daae RL, Ellingsen IH, Nepstad R, Bendiksen EÅ, Reed JL, Senneset G (2017) Spatiotemporal dispersal and deposition of fish farm wastes: a model study from central Norway. Front Mar Sci 4:199

Brooks K, Mahnken C, Nash C (2002) Environmental effects associated with marine netpen waste with emphasis on salmon farming in the Pacific Northwest. In: Stickney RR, McVey J (eds) Responsible marine aquaculture. CABI, Wallingford, p 159-203

Brooks KM, Stierns AR, Backman C (2004) Seven year remediation study at the Carrie Bay Atlantic salmon (Salmo salar) farm in the Broughton Archipelago, British Columbia, Canada. Aquaculture 239:81-123 
Burdett HL, Hennige SJ, Francis FTY, Kamenos NA (2012) The photosynthetic characteristics of red coralline algae, determined using pulse amplitude modulation (PAM) fluorometry. Bot Mar 55:499-509

Burridge L, Weis JS, Cabello F, Pizarro J, Bostick K (2010) Chemical use in salmon aquaculture: a review of current practices and possible environmental effects. Aquaculture 306:7-23

Carroll ML, Cochrane S, Fieler R, Velvin R, White P (2003) Organic enrichment of sediments from salmon farming in Norway: environmental factors, management practices, and monitoring techniques. Aquaculture 226: 165-180

* Castine SA, Bourne DG, Trott LA, McKinnon DA (2009) Sediment microbial community analysis: establishing impacts of aquaculture on a tropical mangrove ecosystem. Aquaculture 297:91-98

Chapman AS, Fletcher RL (2002) Differential effects of sediments on survival and growth of Fucus serratus embryos (Fucales, Phaeophyceae). J Phycol 38:894-903

Chauvaud L, Jean F, Ragueneau O, Thouzeau G (2000) Long-term variation of the Bay of Brest ecosystem: benthic-pelagic coupling revisited. Mar Ecol Prog Ser 200: 35-48

Chazottes V, Le Campion-Alsumard T, Peyrot-Clausade M, Cuet P (2002) The effects of eutrophication-related alterations to coral reef communities on agents and rates of bioerosion (Reunion Island, Indian Ocean). Coral Reefs 21:375-390

Chazottes V, Hutchings P, Osorno A (2017) Impact of an experimental eutrophication on the processes of bioerosion on the reef: One Tree Island, Great Barrier Reef, Australia. Mar Pollut Bull 118:125-130

Coletti G, Basso D, Frixa A (2016) Economic importance of coralline carbonates. In: Riosmena-Rodriguez R, Nelson W, Aguirre J (eds) Rhodolith/maërl beds: a global perspective. Springer, Berlin, p 87-101

Coquereau L, Lossent J, Grall J, Chauvaud L (2017) Marine soundscape shaped by fishing activity. R Soc Open Sci 4: 160606

Cornwall CE, Diaz-Pulido G, Comeau S (2019) Impacts of ocean warming on coralline algal calcification: metaanalysis, knowledge gaps, and key recommendations for future research. Front Mar Sci 6:186

Crawford C, Mitchell IM, Macleod CKA (2001) Video assessment of environmental impacts of salmon farms. ICES J Mar Sci 58:445-452

Davies PS (1989) Short-term growth measurements of corals using an accurate buoyant weighing technique. Mar Biol 101:389-395

FAO (2020) The state of world fisheries and aquaculture 2020 - sustainability in action. FAO, Rome

Frantz BR, Foster MS, Riosmena-Rodriguez R (2005) Clathromorphum nereostratum (Corallinales, Rhodophyta): the oldest alga? J Phycol 41:770-773

Grall J, Glémarec M (1997) Using biotic indices to estimate macrobenthic community perturbations in the Bay of Brest. Estuar Coast Shelf Sci 44:43-53

* Grall J, Hall-Spencer JM (2003) Problems facing maerl conservation in Brittany. Aquat Conserv 13:S55-S64

Hall-Spencer JM (1998) Conservation issues relating to maerl beds as habitats for molluscs. J Conchol Spec Publ 2:271-286

Hall-Spencer JM, Moore PG (2000) Scallop dredging has profound, long-term impacts on maerl habitats. ICES J Mar Sci 57:1407-1415

Hall-Spencer JM, White N, Gillespie E, Gillham K, Foggo A
(2006) Impact of fish farms on maerl beds in strongly tidal areas. Mar Ecol Prog Ser 326:1-9

Hall-Spencer JM, Kelly J, Maggs CA (2008) Assessment of maerl beds in the OSPAR area and the development of a monitoring program. Department of Environment, Heritage and Local Government, Dublin

Hall-Spencer JM, Kelly J, Maggs CA (2010) Background document for maërl beds. OSPAR Biodivers Ser 491. OSPAR Commission, London

Hallock P (1988) The role of nutrient availability in bioerosion: consequences to carbonate buildups. Palaeogeogr Palaeoclimatol Palaeoecol 63:275-291

* Hamoutene D, Salvo F, Donnet S, Dufour SC (2016) The usage of visual indicators in regulatory monitoring at hard-bottom finfish aquaculture sites in Newfoundland (Canada). Mar Pollut Bull 108:232-241

Harianto J, Carey N, Byrne M (2019) respR — an R package for the manipulation and analysis of respirometry data. Methods Ecol Evol 10:912-920

* Haugland BT, Rastrick SPS, Agnalt AL, Husa V, Kutti T, Samuelsen OB (2019) Mortality and reduced photosynthetic performance in sugar kelp Saccharina latissima caused by the salmon-lice therapeutant hydrogen peroxide. Aquacult Environ Interact 11:1-17

*Hauton C, Hall-Spencer JM, Moore PG (2003) An experimental study of the ecological impacts of hydraulic bivalve dredging on maerl. ICES J Mar Sci 60:381-392

*Holmer M, Kristensen E (1992) Impact of marine fish cage farming on metabolism and sulfate reduction of underlying sediments. Mar Ecol Prog Ser 80:191-201

*Hurd CL (2000) Water motion, marine macroalgal physiology, and production. J Phycol 36:453-472

* Hurd CL, Cornwall CE, Currie K, Hepburn CD, McGraw CM, Hunter KA, Boyd PW (2011) Metabolically induced $\mathrm{pH}$ fluctuations by some coastal calcifiers exceed projected 22nd century ocean acidification: a mechanism for differential susceptibility? Glob Change Biol 17: 3254-3262

Iwama GK (1991) Interactions between aquaculture and the environment. Crit Rev Environ Control 21:177-216

Joshi S, Duffy GP, Brown C (2017) Mobility of maerl-siliciclastic mixtures: impact of waves, currents and storm events. Estuar Coast Shelf Sci 189:173-188

Kamenos NA, Moore PG, Hall-Spencer JM (2003) Substratum heterogeneity of dredged vs un-dredged maerl grounds. J Mar Biol Assoc UK 83:411-413

Kamenos NA, Moore PG, Hall-Spencer JM (2004) Nurseryarea function of maerl grounds for juvenile queen scallops Aequipecten opercularis and other invertebrates. Mar Ecol Prog Ser 274:183-189

Karakassis I, Tsapakis M, Hatziyanni E, Papadopoulou KN, Plaiti W (2000) Impact of cage farming of fish on the seabed in three Mediterranean coastal areas. ICES J Mar Sci 57:1462-1471

Kawahara N, Shigematsu K, Miyadai T, Kondo R (2009) Comparison of bacterial communities in fish farm sediments along an organic enrichment gradient. Aquaculture 287:107-113

Keeley NB, Cromey CJ, Goodwin EO, Gibbs MT, Macleod CM (2013) Predictive depositional modelling (DEPOMOD) of the interactive effect of current flow and resuspension on ecological impacts beneath salmon farms. Aquacult Environ Interact 3:275-291

Keeley N, Valdemarsen T, Woodcock S, Holmer M, Husa V, Bannister R (2019) Resilience of dynamic coastal benthic ecosystems in response to large-scale finfish farming. Aquacult Environ Interact 11:161-179 
Kim JH, Lam SMN, Kim KY (2013) Photoacclimation strategies of the temperate coralline alga Corallina officinalis: a perspective on photosynthesis, calcification, photosynthetic pigment contents and growth. Algae 28:355-363

Kursar TA, van der Meer J, Alberte RS (1983) Light-harvesting system of the red alga Gracilaria tikvahiae: I. Biochemical analyses of pigment mutations. Plant Physiol 73:353-360

Kutti T, Ervik A, Hansen PK (2007) Effects of organic effluents from a salmon farm on a fjord system. I. Vertical export and dispersal processes. Aquaculture 262:367-381

La Rosa T, Mirto S, Mazzola A, Maugeri TL (2004) Benthic microbial indicators of fish farm impact in a coastal area of the Tyrrhenian Sea. Aquaculture 230:153-167

Law BA, Hill PS (2019) Spatial and temporal variation in cumulative mass eroded and organic matter percentage in surface sediments near areas of active salmon aquaculture. Aquacult Environ Interact 11:305-320

Law BA, Hill PS, Maier I, Milligan TG, Page F (2014) Size, settling velocity and density of small suspended particles at an active salmon aquaculture site. Aquacult Environ Interact 6:29-42

Koya Y, Lubinevsky H, Rosenfeld M, Kramarsky-Winter E (2004) Nutrient enrichment caused by in situ fish farms at Eilat, Red Sea is detrimental to coral reproduction. Mar Pollut Bull 49:344-353

Marrack EC (1999) The relationship between water motion and living rhodolith beds in the Southwestern Gulf of California, Mexico. Palaios 14:159

Martin S, Gattuso JP (2009) Response of Mediterranean coralline algae to ocean acidification and elevated temperature. Glob Change Biol 15:2089-2100

*Martin S, Castets MD, Clavier J (2006) Primary production, respiration and calcification of the temperate free-living coralline alga Lithothamnion corallioides. Aquat Bot 85: 121-128

Melbourne LA, Hernández-Kantún JJ, Russell S, Brodie J (2017) There is more to maerl than meets the eye: DNA barcoding reveals a new species in Britain, Lithothamnion erinaceum sp. nov. (Hapalidiales, Rhodophyta). Eur J Phycol 52:166-178

Mowi (2020) Salmon farming industry handbook 2020. https://mowi.com/it/wp-content/uploads/sites/16/2020/ 06/Mowi-Salmon-Farming-Industry-Handbook-2020.pdf

Nelson WA (2009) Calcified macroalgae - critical to coastal ecosystems and vulnerable to change: a review. Mar Freshw Res 60:787

Peña V, Bárbara I, Grall J, Maggs CA, Hall-Spencer JM (2014) The diversity of seaweeds on maerl in the NE Atlantic. Mar Biodivers 44:533-551

Peña V, Bélanger D, Gagnon P, Richards JL and others (2021) Lithothamnion (Hapalidiales, Rhodophyta) in the changing Arctic and Subarctic: DNA sequencing of type and recent specimens provides a systematic foundation. Eur J Phycol, doi:10.1080/09670262.2021.1880643

Pereira DC, Trigueiro TG, Colepicolo P, Marinho-Soriano E (2012) Seasonal changes in the pigment composition of natural population of Gracilaria domingensis (Gracilariales. Rhodophyta). Rev Bras Farmacogn 22:874-880

Potin P, Floc'h JY, Augris C, Cabioch J, Tessier PG (1990) Annual growth rate of the calcareous red alga Lithothamnion corallioides (Corallinales, Rhodophyta) in the Bay of Brest, France. Hydrobiologia 204:263-267

R Core Team (2020) R: a language and environment for statistical computing. R Foundation for Statistical Computing, Vienna

Riosmena-Rodriguez R, Nelson W, Aguirre J (2016) Rhodo- lith/maerl beds: a global perspective. Springer, Berlin

Ritchie RJ (2008) Universal chlorophyll equations for estimating chlorophylls $a, b, c$, and $d$ and total chlorophylls in natural assemblages of photosynthetic organisms using acetone, methanol, or ethanol solvents. Photosynthetica 46: $115-126$

* Roberts RD, Kuhl M, Glud RN, Rysgaard S (2002) Primary production of crustose coralline red algae in a high Arctic fjord. J Phycol 38:273-283

* Sanz-Lázaro C, Belando MD, Marín-Guirao L, NavarreteMier F, Marín A (2011) Relationship between sedimentation rates and benthic impact on Maërl beds derived from fish farming in the Mediterranean. Mar Environ Res 71:22-30

* Short JA, Pedersen O, Kendrick GA (2015) Turf algal epiphytes metabolically induce local $\mathrm{pH}$ increase, with implications for underlying coralline algae under ocean acidification. Estuar Coast Shelf Sci 164:463-470

Sordo L, Santos R, Barrote I, Freitas C, Silva J (2020) Seasonal photosynthesis, respiration, and calcification of a temperate maërl bed in southern Portugal. Front Mar Sci 7:136

Soto D, Norambuena F (2004) Evaluation of salmon farming effects on marine systems in the inner seas of southern Chile: a large-scale mensurative experiment. J Appl Ichthyol 20:493-501

Steller DL, Riosmena-Rodríguez R, Foster MS, Roberts CA (2003) Rhodolith bed diversity in the Gulf of California: the importance of rhodolith structure and consequences of disturbance. Aquat Conserv 13:S5-S20

* Steller DL, Hernandez-Ayon JM, Riosmena-Rodriguez R, Cabello-Pasini A (2007) Effect of temperature on photosynthesis, growth and calcification rates of the free-living coralline alga Lithophyllum margaritae. Cienc Mar 33: 441-456

* Stengel DB, Conde-Álvarez R, Connan S, Nitschke U and others (2014) Short-term effects of $\mathrm{CO}_{2}$, nutrients and temperature on three marine macroalgae under solar radiation. Aquat Biol 22:159-176

* Sweetman AK, Norling K, Gunderstad C, Haugland BT, Dale T (2014) Benthic ecosystem functioning beneath fish farms in different hydrodynamic environments. Limnol Oceanogr 59:1139-1151

* Taranger GL, Karlsen Ø, Bannister RJ, Glover KA and others (2015) Risk assessment of the environmental impact of Norwegian Atlantic salmon farming. ICES J Mar Sci 72: 997-1021

Torres PB, Chow F, Furlan CM, Mandelli F, Mercadante A, dos Santos DYAC (2014) Standardization of a protocol to extract and analyze chlorophyll $a$ and carotenoids in Gracilaria tenuistipitata Var. Liui. Zhang and Xia (Rhodophyta). Braz J Oceanogr 62:57-63

*Vásquez-Elizondo RM, Enríquez S (2016) Coralline algal physiology is more adversely affected by elevated temperature than reduced $\mathrm{pH}$. Sci Rep 6:19030

*White CA, Nichols PD, Ross DJ, Dempster T (2017) Dispersal and assimilation of an aquaculture waste subsidy in a low productivity coastal environment. Mar Pollut Bull 120: 309-321

Wilson S, Blake C, Berges JA, Maggs CA (2004) Environmental tolerances of free-living coralline algae (maerl): implications for European marine conservation. Biol Conserv 120:279-289

* Yakushev EV, Wallhead P, Renaud PE, Ilinskaya A and others (2020) Understanding the biogeochemical impacts of fish farms using a benthic-pelagic model. Water 12:2384 